\title{
HEAT STRESS IN THE URBAN AND SUBURBAN LANDSCAPE AND ITS SPATIAL DIFFERENTIATION THROUGH THE EXAMPLE OF A MEDIUM-SIZED CITY
}

\author{
Miroslav Vysoudil*, CSc., Michal Lehnert*, \\ MSc., Petr Kladivo**, PhD. \\ *Department of Geography, Faculty of Science, Palacký University \\ Olomouc, 17. listopadu 12, CZ-77I 46 Olomouc, Czech Republic \\ **Department of Geography, Faculty of Economics, University of West Bohemia \\ Tylova 18, CZ-306 I4 Plzeň, Czech Republic \\ e-mail: miroslav.vysoudil@upol.cz, michal.lehnert@gmail.com, pkladivo@kge.zcu.cz
}

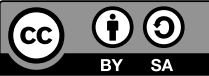

Original scientific article

COBISS 1.01

DOI: $10.4312 /$ dela.46.7.163-182

\begin{abstract}
The spatial distribution of heat stress in a Central European city and its surroundings was examined. We evaluated the length of time for which the threshold values of Humidex and air temperatures were exceeded at individual stations. The longest interval of temperature discomfort was detected at the border of open mid-rise development and open spaces. The shortest intervals were found in compact mid-rise development and near a forest. There are spatial differences between locations with long periods of high temperatures and locations with long intervals of high Humidex values. However, when the heat stress is being assessed in relation to the mortality rate, Humidex does not show better results than the air temperature.
\end{abstract}

Key words: air temperature, heat stress, heat wave, Humidex, humidity, mortality, urban climate

\section{TOPLOTNI STRES V URBANEM IN SUBURBANEM OKOLJU TER NJEGOVA PROSTORSKA SPREMENLJIVOST NA PRIMERU SREDNJE VELIKEGA MESTA}

\section{Izvleček}

Članek obravnava prostorsko razporeditev toplotnega stresa v srednjeevropskem mestu in njegovi okolici. Preučevali smo čas, ko so bile na merskih postajah presežene mejne vrednosti indeksa Humidex in zračnih temperatur. Najdaljše obdobje neugodnih temperatur je bilo na stiku med srednje visokimi zgradbami in odprtim prostorom, najkrajše v sklenjeno pozidanih delih in blizu gozda. Ugotovili smo razlike v razporeditvi postaj z dolgimi obdobji visokih temperatur in postaj z dolgimi intervali visokih vrednosti indeksa 
Humidex. Pri vrednotenju toplotnega stresa z vidika mortalitete pa Humidex ni dal boljših rezultatov kot podatki o temperaturah zraka.

Ključne besede: temperatura zraka, toplotni stres, vročinski val, Humidex, humidnost, mortaliteta, mestna klima

\section{INTRODUCTION}

The World Meteorological Organization (WMO) and the Intergovernmental Panel on Climate Change (IPCC) have repeatedly warned of the serious impact of climate change on human health (recently IPPC, 2014a). Patz et al. (2005) marked the temperate latitudes for areas with the assumption of high excess mortality resulting from thermal stress. Studies on the effects of extremely hot weather and the mitigation of its impact on human health in these areas therefore rightfully belong to the very topical and frequent research subjects.

Over the last decade dozens of papers were published which deal with heat stress. Gradually, a paradigm has come into existence in which the main environmental factors causing heat stress, besides the dry bulb temperature, also include the wet bulb temperature, radiant temperature, air humidity, and air movement (Epstein, Moran, 2006). Apart from the individual parameters of each person (e. g. clothes, age, gender or health condition), it appears that the impact of extremely hot weather on human health also depends on the amplitude of the temperature, the time of the occurrence of a heatwave within the climate season, the overall state of public health, and the age structure and experience of the population with heatwaves (Curriero et al., 2002; Kovats, Hajat, 2008).

Disproportionately less attention is paid to the study of the environment in which the individual happens to be at the time of the event. Clarke (1972), Tan et al. (2010) and some others describe the relationship between the urban heat island and mortality in extremely hot weather; however, the new findings about the urban climate suggest that the differentiation of the temperature field of the city is higher than previously assumed (Houet, Pigeon, 2011; Bokwa, 2011; Stewart, Oke, Krayenhoff, 2014; Lelovics et al., 2014; Bokwa et al., 2015; Lehnert et al., 2015; Středová, Středa, Litschmann, 2015). These new findings call for more detailed studies of the spatial differentiation of the heat stress in cities and their surroundings.

The primary objective of the study is to evaluate the spatial variability of heat stress in the medium-sized city through the example of Olomouc and its surroundings (Czech Republic). Following this evaluation, we will compare the explanatory power of the heat stress values provided by standard temperature characteristics and by Humidex as one of the direct bioclimatic indices that is frequently applied in moderate climate in Europe (Lavalle et al., 2006; Dankers, Hiederer, 2008; Litschmann, Rožnovský, 2009; Tomáš, 2012; Błażejczyk, Twardosz, 2010; Bokwa, Limanówka, 2014). 


\section{METHODS}

\section{I Station network}

From administrative point of view, the area of interest corresponds with Olomouc administrative districts of municipality with extended powers excluding Libavá military area. The height range of the area is between 200 and 600 meters above sea level. More than $90 \%$ of the total of 162,000 inhabitants live at an altitude of 300 meters above sea level. About $60 \%$ of the population live in the largest city Olomouc. The city of Olomouc has passed through several substantial stages of development. Consequently, there are historic buildings in the city center, parks, brownfields, housing estates, residential areas, industrial parks, shopping centers, and satellite settlements. The landscape around the towns has a mainly agricultural character. The climate in Olomouc has a typical Central European character (for more details see Vysoudil et al., 2012).

The Metropolitan Station System Olomouc was established in 2009 to study the specific needs of the urban and local climate. In 2011, it had 24 stations, its maximum number, and, therefore, this year was selected for a detailed spatial analysis of temperature and humidity characteristics. The network design is approximately radial. Of the total number of 24 stations, 14 stations of two different types recorded simultaneously the air

Figure 1: Olomouc and surroundings and selected stations of the Metropolitan Station System of Olomouc.

Slika 1: Razporeditev izbranih merskih postaj metropolitanskega omrežja postaj v Olomoucu in okolici.

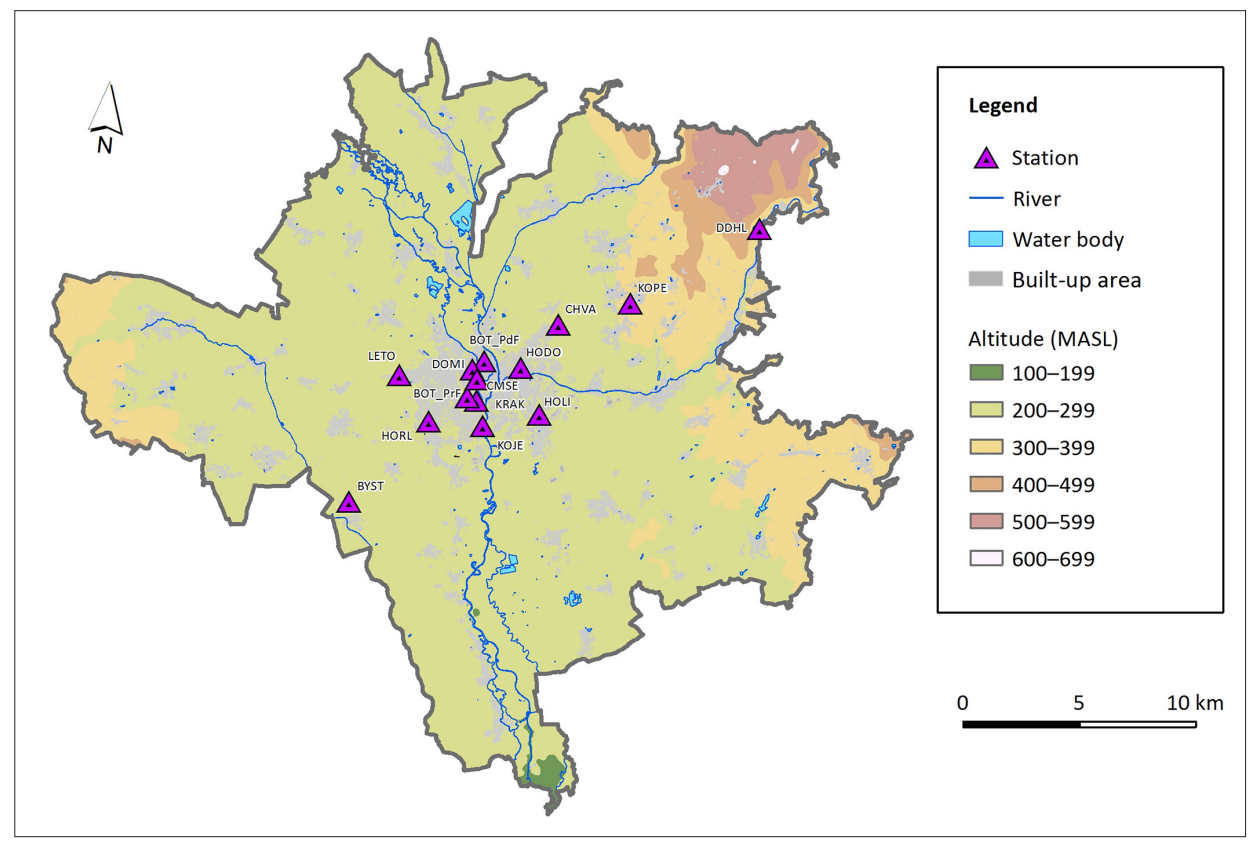


temperature and relative humidity at a height of $1.5 \mathrm{~m}$ and therefore were suitable for this particular study. The stations BOT_PdF, BYST, DOMI, HOLI, LETO, and KOPE were fully automated (Figure 2a). The reading interval at these stations was 10 minutes. On the other hand, the stations BOT_PrF, CMSE, HODO, HOLI, CHVA, and KOJE measured only the temperature and humidity (Figure $2 \mathrm{~b}$ ). The data were recorded in the internal memory sensor at 30-minute intervals. The temperature and humidity sensors of all the stations were located in the radiation shield and were not actively ventilated. Detailed information on the individual stations is provided in Table 1. The surrounding of stations was described using the local climate zones (Lehnert et al., 2015); see Table 2.

Figure 2: Examples of the stations of Metropolitan Station System Olomouc: a) DOMI; b) CHVA. Slika 2: Primera merskih postaj iz metropolitanskega omrežja postaj Olomouc: a) DOMI; b) CHVA.
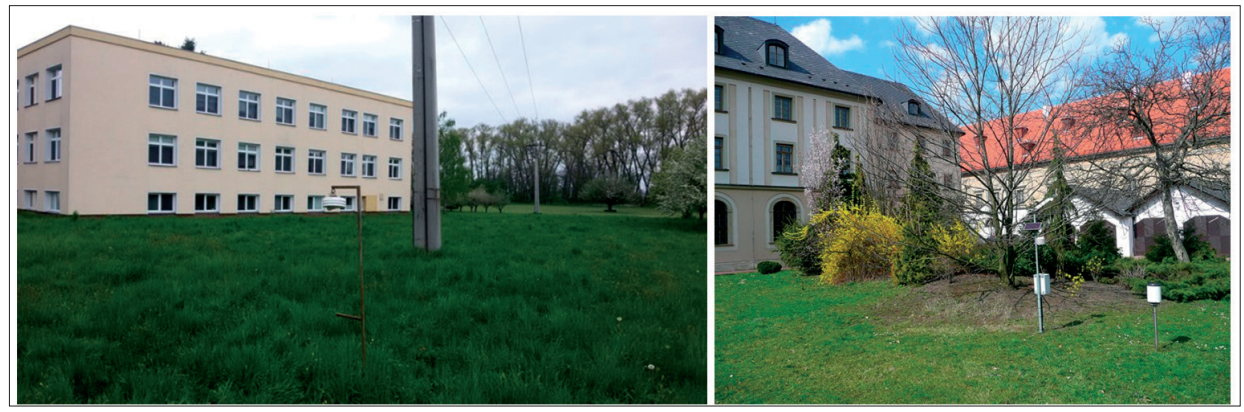

Table 1: Metadata of selected stations of the Metropolitan Station System of Olomouc. Preglednica 1: Metapodatki za izbrane merske postaje metropolitanskega sistema postaj Olomouc.

\begin{tabular}{|l|l|l|l|l|l|l|l|}
\hline Station & $\begin{array}{l}\text { Start-up } \\
\text { date }\end{array}$ & Status & Sensor type & $\begin{array}{l}\text { Sensor } \\
\text { accuracy }\end{array}$ & $\begin{array}{l}\text { Altitude } \\
\text { (above } \\
\text { see level) }\end{array}$ & Latitude & Longitude \\
\hline BOT_PdF & 8.4 .2010 & working & $\begin{array}{l}\text { SHT75K } \\
\text { (Sensirion) }\end{array}$ & $\pm 0.3^{\circ} \mathrm{C}$ & $211 \mathrm{~m}$ & $49^{\circ} 36.016^{\prime} \mathrm{N}$ & $17^{\circ} 15.457^{\prime} \mathrm{E}$ \\
\hline BOT_PrF & 1.4 .2008 & $\begin{array}{l}\text { stopped } \\
(1 / 1 / 2012)\end{array}$ & $\begin{array}{l}\text { MicroLog } \\
\text { EC750 (Fourier) }\end{array}$ & $\pm 0.2^{\circ} \mathrm{C}$ & $213 \mathrm{~m}$ & $49^{\circ} 35.155^{\prime} \mathrm{N}$ & $17^{\circ} 15.849^{\prime} \mathrm{E}$ \\
\hline BYST & 23.10 .2009 & working & $\begin{array}{l}\text { SHT75K } \\
\text { (Sensirion) }\end{array}$ & $\pm 0.3^{\circ} \mathrm{C}$ & $218 \mathrm{~m}$ & $49^{\circ} 35.557^{\prime} \mathrm{N}$ & $17^{\circ} 11.261^{\prime} \mathrm{E}$ \\
\hline CHVA & 24.3 .2009 & working & $\begin{array}{l}\text { MicroLog } \\
\text { EC750(Fourier) }\end{array}$ & $\pm 0.2^{\circ} \mathrm{C}$ & $216 \mathrm{~m}$ & $49^{\circ} 37.010^{\prime} \mathrm{N}$ & $17^{\circ} 17.882^{\prime} \mathrm{E}$ \\
\hline CMSE & 27.4 .2007 & $\begin{array}{l}\text { stopped } \\
(1 / 1 / 2012)\end{array}$ & $\begin{array}{l}\text { MicroLog } \\
\text { EC750(Fourier) }\end{array}$ & $\pm 0.2^{\circ} \mathrm{C}$ & $237 \mathrm{~m}$ & $49^{\circ} 35.591^{\prime} \mathrm{N}$ & $17^{\circ} 15.243^{\prime} \mathrm{E}$ \\
\hline DDHL & 4.4 .2007 & working & $\begin{array}{l}\text { SHT75K } \\
\text { (Sensirion) }\end{array}$ & $\pm 0.3^{\circ} \mathrm{C}$ & $307 \mathrm{~m}$ & $49^{\circ} 39.597^{\prime} \mathrm{N}$ & $17^{\circ} 24.555^{\prime} \mathrm{E}$ \\
\hline DOMI & 8.4 .2010 & working & $\begin{array}{l}\text { SHT75K } \\
\text { (Sensirion) }\end{array}$ & $\pm 0.3^{\circ} \mathrm{C}$ & $220 \mathrm{~m}$ & $49^{\circ} 35.810^{\prime} \mathrm{N}$ & $17^{\circ} 15.044^{\prime} \mathrm{E}$ \\
\hline
\end{tabular}


Heat Stress in the Urban and Suburban Landscape...

\begin{tabular}{|l|l|l|l|l|l|l|l|}
\hline Station & $\begin{array}{l}\text { Start-up } \\
\text { date }\end{array}$ & Status & Sensor type & $\begin{array}{l}\text { Sensor } \\
\text { accuracy }\end{array}$ & $\begin{array}{l}\text { Altitude } \\
\text { above } \\
\text { see level) }\end{array}$ & Latitude & Longitude \\
\hline HODO & 1.1 .2009 & $\begin{array}{l}\text { stopped } \\
(1 / 1 / 2012)\end{array}$ & $\begin{array}{l}\text { MicroLog } \\
\text { EC750 (Fourier) }\end{array}$ & $\pm 0.2^{\circ} \mathrm{C}$ & $214 \mathrm{~m}$ & $49^{\circ} 35.994^{\prime} \mathrm{N}$ & $17^{\circ} 16.738^{\prime} \mathrm{E}$ \\
\hline HOLI & 8.5 .2009 & working & $\begin{array}{l}\text { SHT75K } \\
\text { (Sensirion) }\end{array}$ & $\pm 0.3^{\circ} \mathrm{C}$ & $217 \mathrm{~m}$ & $49^{\circ} 34.664^{\prime} \mathrm{N}$ & $17^{\circ} 17.578^{\prime} \mathrm{E}$ \\
\hline HORL & 1.2 .2010 & $\begin{array}{l}\text { stopped } \\
(1 / 1 / 2012)\end{array}$ & $\begin{array}{l}\text { MicroLog } \\
\text { EC750 (Fourier) }\end{array}$ & $\pm 0.2^{\circ} \mathrm{C}$ & $233 \mathrm{~m}$ & $49^{\circ} 34.606^{\prime} \mathrm{N}$ & $17^{\circ} 13.949^{\prime} \mathrm{E}$ \\
\hline KOJE & 30.5 .2007 & working & $\begin{array}{l}\text { MicroLog } \\
\text { EC750 (Fourier) }\end{array}$ & $\pm 0.2^{\circ} \mathrm{C}$ & $210 \mathrm{~m}$ & $49^{\circ} 34.545^{\prime} \mathrm{N}$ & $17^{\circ} 15.625^{\prime} \mathrm{E}$ \\
\hline KOPE & 8.4 .2010 & working & $\begin{array}{l}\text { SHT75K } \\
\text { (Sensirion) }\end{array}$ & $\pm 0.3^{\circ} \mathrm{C}$ & $362 \mathrm{~m}$ & $49^{\circ} 37.646^{\prime} \mathrm{N}$ & $17^{\circ} 20.330^{\prime} \mathrm{E}$ \\
\hline KRAK & 1.4 .2009 & $\begin{array}{l}\text { stopped } \\
(1 / 1 / 2012)\end{array}$ & $\begin{array}{l}\text { MicroLog } \\
\text { EC750 (Fourier) }\end{array}$ & $\pm 0.2^{\circ} \mathrm{C}$ & $211 \mathrm{~m}$ & $49^{\circ} 35.109^{\prime} \mathrm{N}$ & $17^{\circ} 15.317^{\prime} \mathrm{E}$ \\
\hline LETO & 27.3 .2007 & working & $\begin{array}{l}\text { SHT75K } \\
\text { (Sensirion) }\end{array}$ & $\pm 0.3^{\circ} \mathrm{C}$ & $257 \mathrm{~m}$ & $49^{\circ} 35.482^{\prime} \mathrm{N}$ & $17^{\circ} 12.582^{\prime} \mathrm{E}$ \\
\hline
\end{tabular}

Table 2: Characteristics of the stations' surroundings.

Preglednica 2: Značilnosti bližnje okolice merskih postaj.

\begin{tabular}{|c|c|c|c|c|c|}
\hline Station & $\begin{array}{l}\text { Local climate } \\
\text { zone }\end{array}$ & $\begin{array}{l}\text { Representativeness } \\
\text { for local climate }\end{array}$ & \begin{tabular}{|l} 
Significant \\
microclimate \\
effect
\end{tabular} & $\begin{array}{c}\text { Sky view } \\
\text { factor }(\%)\end{array}$ & $\begin{array}{l}\text { Active surface in } \\
\text { microscale radius } \\
(20 \mathrm{~m})\end{array}$ \\
\hline BOT_PdF & $9_{5}$ & high & no & 84 & grass, buildings, trees \\
\hline BOT_PrF & $9_{5}$ & limited & no & 72 & grass, trees, pavement \\
\hline BYST & 9 & high & no & 81 & grass, trees \\
\hline CHVA & $\mathrm{B}_{\mathrm{Dw}}$ & high & no & 78 & grass, trees, buildings \\
\hline CMSE & $22_{\mathrm{cc}}$ & limited & yes & 25 & $\begin{array}{l}\text { grass, pavement, } \\
\text { buildings, bush }\end{array}$ \\
\hline DDHL & $A_{B}$ & limited & no & 73 & $\begin{array}{l}\text { grass, trees, } \\
\text { pavement, buildings }\end{array}$ \\
\hline DOMI & $22_{\text {Boc }}$ & limited & yes & 70 & $\begin{array}{l}\text { grass, trees, } \\
\text { pavement, buildings }\end{array}$ \\
\hline HODO & 5 & limited & yes & 48 & $\begin{array}{l}\text { grass, asphalt, } \\
\text { buildings }\end{array}$ \\
\hline HOLI & $5_{6}$ & high & no & 84 & $\begin{array}{l}\text { grass, asphalt, } \\
\text { buildings }\end{array}$ \\
\hline HORL & 4 & high & no & 49 & $\begin{array}{l}\text { grass, trees, gravel, } \\
\text { asphalt, buildings } \\
\end{array}$ \\
\hline KOJE & $9_{5}$ & limited & yes & 70 & $\begin{array}{l}\text { grass, trees, asphalt, } \\
\text { buildings, pavement }\end{array}$ \\
\hline KOPE & 95 & limited & no & 74 & grass, trees, gravel \\
\hline KRAK & 5 & limited & yes & 67 & $\begin{array}{l}\text { grass, buildings, } \\
\text { pavement, trees }\end{array}$ \\
\hline LETO & $9_{5}$ & high & no & 100 & $\begin{array}{l}\text { grass, asphalt, } \\
\text { buildings }\end{array}$ \\
\hline
\end{tabular}




\subsection{Data processing}

Considering the heat stress characteristics presented, we worked with the data for the summer half-year. The data series used underwent basic quality control and incorrect or missing data were corrected and/or calculated using standard methods in accordance with WMO (2008). The averages were calculated as the arithmetical average of all the measurements at 30-minute intervals. The total number of hours during which the threshold values of $25.0^{\circ} \mathrm{C}, 30.0^{\circ} \mathrm{C}$, and $35.0^{\circ} \mathrm{C}$ were exceeded was determined from the measurements at 30-minute intervals. If the temperature exceeded the given threshold temperature in a certain time period, the whole half-hour was counted (i.e., we assumed that a given limit was or was not exceeded during the entire interval of 15 minutes before and after the measurement).

Humidex was calculated according to a standard formula [1] as presented in the original paper by Masterton and Richardson (1979):

$$
\begin{gathered}
H D=t_{a}+\frac{5}{9} \cdot\left(p_{a s}-10\right) \\
p_{a s}=6,112 \cdot\left(10 \frac{7,5 \cdot t_{a}}{237,7+t_{a}}\right) \cdot \frac{R H}{100}
\end{gathered}
$$

where $t_{a}$ is (ambient) temperature $\left({ }^{\circ} \mathrm{C}\right)$ and $R H$ relative humidity $(\%)$.

Using data series of temperature and humidity measured at 30-minute intervals, $\mathrm{Hu}-$ midex data series was established for the same intervals at the same time resolution. The cumulative time values exceeding certain Humidex values were then calculated analogously as in the case of the temperatures. The threshold Humidex values of 30 (some discomfort), 40 (great discomfort), and 46 (dangerous) were chosen as standardly used. To obtain detailed results, in some of our calculations we also used the less frequently used level of 35 (evident discomfort). Besides Humidex, we also separately presented water vapor pressure according to formula [2] for a detailed spatial analysis of the causes of the spatial variability of heat stress.

We selected a station that on average best represents the selected area to determine representative Humidex temperature characteristics and values on regional level. The selection of such a representative station for Olomouc and its surroundings was performed by calculating the daily temperature differences at the individual stations from the average of all measurements throughout the summer half-year at 30-minute intervals, as well as for the days on which the Humidex value reached 30 (to exclude any distortion caused by a state that corresponded to lower temperatures or Humidex values).

The mortality data for the Olomouc and surroundings for individual days were provided by the Czech Statistical Office in Olomouc. These are the official statistics compiled on the basis of individual record sheets up to the level of municipalities. We always included all the dead people domiciled in the area of interest. The boundary 
of temperature intervals, or Humidex values, which were then compared with mortality, were established in order to reflect the selected threshold values of the maximum temperatures and Humidex values. The second criterion was adherence to the absolute frequency of intervals with a value of at least 10 . No values below $10.0^{\circ} \mathrm{C}$ or Humidex values under 10 (H10) were included because of the nature of the Humidex equation and the objectives of the study.

\section{RESULTS}

\section{I Detailed spatial distribution of heat stress in $20 \mathrm{II}$}

Primarily, we focused on the description of the extent to which the threshold air temperature values at individual stations were exceeded. In 2011, as well as in all the other years in the reference period 2010-2014, the occurrence of daily maximum temperatures above $35.0^{\circ} \mathrm{C}$ was not very frequent. According to the detailed analysis of 2011 , the air temperature value only exceeded $35.0^{\circ} \mathrm{C}$ at seven of the fourteen stations monitored (Table 3). Therefore, any meaningful information is provided mainly by the data on the length of the time interval of temperatures above $30.0^{\circ} \mathrm{C}$. In this case, the longest intervals were found at the stations KOJE, BOT_PrF, BOT_PdF, DOMI, and KRAK. Their common denominator is their location at the boundary of a medium, but not quite compact urban development (open mid-rise) and in relatively open and well sunlit surfaces with low vegetation, scattered trees and communication networks.

The ratio of the length of time intervals at the individual stations does not change much even when the length of the interval of temperatures above $25.0^{\circ} \mathrm{C}$ is analyzed. The exceptions are the KOJE and CHVA stations, which belonged among those stations with the highest values with regard to the periods exceeding temperatures above $35.0^{\circ} \mathrm{C}$ or $30.0^{\circ} \mathrm{C}$, while for the total time in which the temperature exceeded $25.0^{\circ} \mathrm{C}$ it belonged among the rather average stations (Table 3). Such behavior has its cause in the shape of the curve of the daily temperature at the onset of the daily maxima which, like the subsequent decline, is steep because of the high level of insolation near the stations and generally below-average mean temperatures of these stations.

The stations with the lowest total of intervals with temperatures exceeding $30.0^{\circ} \mathrm{C}$ and $25.0^{\circ} \mathrm{C}$ include HODO and - by a huge margin - DDHL and CMSE. All these stations were located in shady environments. In the case of CMSE and HODO, the shady environment is created by buildings. CMSE is located in an enclosed courtyard in the historic downtown area and HODO in older development consisting of multi-storey houses and former workshops. DDHL is located in an enclosed valley extending in a north-south direction with wooded slopes and minimal development (see Table 2). 
Table 3: The number of hours in which the given threshold temperatures and Humidex values at Metropolitan Station System Olomouc stations were exceeded in 2011.

Preglednica 3: Število ur, ko so bile presežene mejne temperature in vrednosti indeksa Humidex na merskih postajah metropolitanskega sistema postaj Olomouc.

\begin{tabular}{|c|c|c|c|c|c|c|c|c|c|c|c|c|}
\hline $\begin{array}{l}\text { Rank- } \\
\text { ing }\end{array}$ & Station & $\begin{array}{l}\text { Hu- } \\
\text { midex } \\
\text { H40 }\end{array}$ & Station & \begin{tabular}{|l|} 
Hu- \\
midex \\
H35
\end{tabular} & Station & $\begin{array}{l}\text { Hu- } \\
\text { midex } \\
\text { H30 }\end{array}$ & Station & \begin{tabular}{|l|} 
Tem- \\
pera- \\
ture \\
$35^{\circ} \mathrm{C}$ \\
\end{tabular} & Station & $\begin{array}{l}\text { Tem- } \\
\text { pera- } \\
\text { ture } \\
3^{\circ} \mathrm{C} \\
\end{array}$ & Station & $\begin{array}{l}\text { Tem- } \\
\text { pera- } \\
\text { ture } \\
25^{\circ} \mathrm{C}\end{array}$ \\
\hline 1. & KRAK & 32.0 & KRAK & 130.5 & KRAK & 539.0 & $\begin{array}{l}\text { BOT_ } \\
\text { PrF }\end{array}$ & 5.0 & KOJE & 96.5 & $\begin{array}{l}\text { BOT_ } \\
\text { PrF }\end{array}$ & 573.0 \\
\hline 2. & BYST & 30.0 & KOJE & 122.0 & \begin{tabular}{|l|}
$\mathrm{BOT}_{-}$ \\
$\mathrm{PrF}$
\end{tabular} & 423.0 & KRAK & 4.5 & $\begin{array}{l}\mathrm{BOT}_{-} \\
\mathrm{PrF}\end{array}$ & 92.5 & $\begin{array}{l}\mathrm{BOT}_{-} \\
\mathrm{PdF}\end{array}$ & 556.0 \\
\hline 3. & KOJE & 25.5 & $\begin{array}{l}\mathrm{BOT}_{-} \\
\mathrm{PrF}\end{array}$ & 112.0 & HORL & 413.0 & CHVA & 4.0 & $\begin{array}{l}\mathrm{BOT}_{-} \\
\mathrm{PdF}\end{array}$ & 88.4 & KRAK & 541.5 \\
\hline 4. & HORL & 24.5 & HORL & 111.5 & CHVA & 411.5 & KOJE & 2.0 & DOMI & 84.5 & HOLI & 503.0 \\
\hline 5. & $\begin{array}{l}\mathrm{BOT}_{-} \\
\mathrm{PdF}\end{array}$ & 23.0 & $\begin{array}{l}\mathrm{BOT}_{-} \\
\mathrm{PdF}\end{array}$ & 110.0 & $\begin{array}{l}\mathrm{BOT}_{-} \\
\mathrm{PdF}\end{array}$ & 402.0 & DOMI & 1.5 & KRAK & 84.5 & DOMI & 498.0 \\
\hline 6. & CHVA & 21.5 & CHVA & 108.0 & KOJE & 400.0 & $\begin{array}{l}\mathrm{BOT}_{-} \\
\mathrm{PdF}\end{array}$ & 1.0 & CHVA & 76.0 & CHVA & 493.0 \\
\hline 7. & DOMI & 20.0 & BYST & 100.5 & DOMI & 382.5 & HOLI & 0.5 & HOLI & 75.5 & KOJE & 445.0 \\
\hline 8. & $\begin{array}{l}\mathrm{BOT}_{-} \\
\mathrm{PrF}\end{array}$ & 16.5 & DOMI & 98.0 & BYST & 382.0 & BYST & 0.0 & KOPE & 61.0 & BYST & 422.0 \\
\hline 9. & KOPE & 16.0 & HODO & 91.0 & HODO & 362.5 & DDHL & 0.0 & BYST & 55.5 & HORL & 414.0 \\
\hline 10. & HODO & 15.5 & KOPE & 87.5 & HOLI & 359.0 & KOPE & 0.0 & HORL & 51.0 & KOPE & 395.0 \\
\hline 11. & LETO & 13.5 & DDHL & 75.5 & KOPE & 327.0 & LETO & 0.0 & LETO & 41.0 & LETO & 393.0 \\
\hline 12. & HOLI & 11.0 & HOLI & 75.5 & LETO & 322.0 & CMSE & 0.0 & HODO & 29.5 & HODO & 371.0 \\
\hline 13. & DDHL & 8.5 & LETO & 68.5 & DDHL & 293.0 & HODO & 0.0 & DDHL & 27.5 & CMSE & 316.5 \\
\hline 14. & CMSE & 0.0 & CMSE & 31.0 & CMSE & 231.0 & HORL & 0.0 & CMSE & 19.0 & DDHL & 280.0 \\
\hline
\end{tabular}

From Table 3 it is obvious that the spatial distribution of the length of the intervals during which the selected Humidex values were exceeded does not completely correspond to the distribution of the length of the intervals during which the selected temperatures were exceeded. These differences are caused by the spatial-temporal variability of water vapor pressure. The impact of the water vapor pressure and its spatial variability on the formation of heat stress is obvious from Figure 3, where the differences between the average temperature and Humidex at individual stations are shown. As indicated in Figure 3, the greatest impact of water vapor pressure on the formation of heat stress can be expected especially at the KRAK station and also at the stations KOJE, HODO, HORL, and BYS, while, on the contrary, the smallest impact is at the stations CMSE, HOLI, and KOPE.

It was found that in the case of intervals that exceed the Humidex threshold values the most affected station is KRAK (Table 3). Figure $4 \mathrm{~g}$ shows that higher totals of the occurrence of discomfort temperatures at this station are caused by a combination of high midday and afternoon air temperatures and the high mean water vapor pressure. The high vapor pressure values at the KRAK station occur as a result of a microclimatic effect caused by the artificial irrigation of the nearby garden. The high growth in temperature at the HODO station has the same reason. The temperatures and vapor pressures do not reach such high values here because of the substantial shadowing of the station. 
Figure 3: The difference between the average Humidex value and average air temperature at the Metropolitan Station System Olomouc stations (Series 1 for the summer half-year, Series 2 during the heatwave between August $22^{\text {nd }}$ to August 26 ${ }^{\text {th }}, 2011$ ).

Slika 3: Razlike med povprečno vrednostjo indeksa Humidex in povprečnimi temperaturami zraka na merskih postajah metropolitanskega sistema postaj Olomouc (niz 1 za poletno polovico leta, niz 2 za čas vročinskega vala od 22. do 26. avgusta 2011).

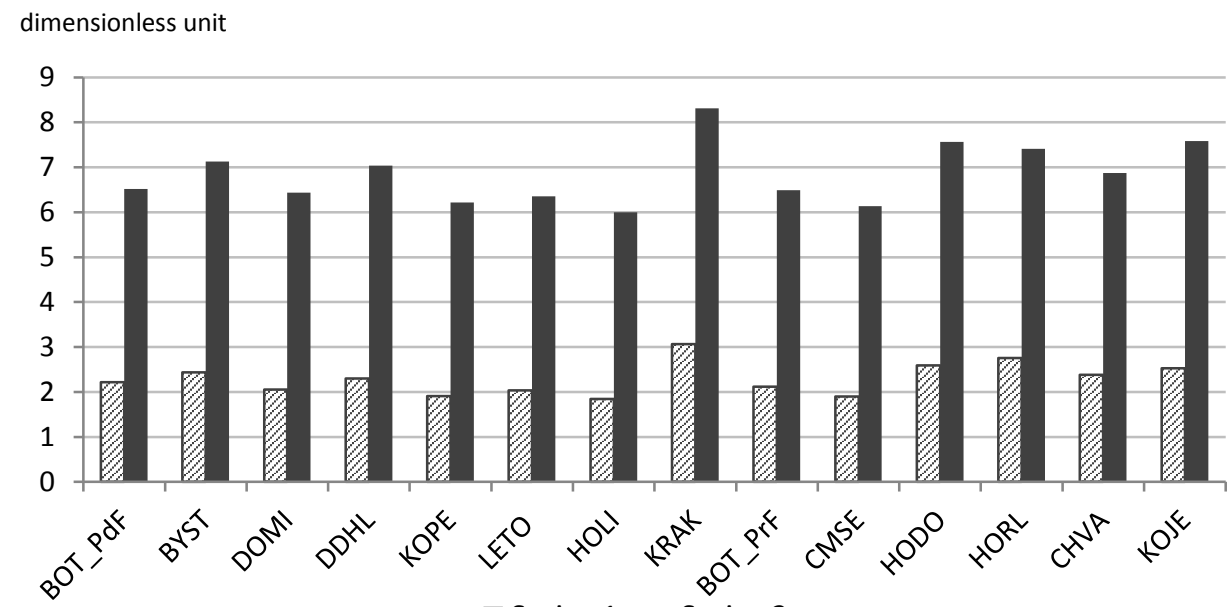

口Series 1 - Series 2

A significant influence of the local climate can be seen in the high total of intervals of great discomfort (H40) at the BYST station, especially because the totals of some discomfort (H30) at this station are only average (see Table 3). It is obvious (Figure 4a) that this condition is due to a significant amplitude in the daily course of the air temperature and water vapor pressure. Reason for this may be the low plants on the waterlogged black soil in the immediate vicinity of the station. Another station with high totals of intervals of great discomfort (H40) but relatively moderate totals of interval of some discomfort (H30) is the KOJE station, which again lies near a source of air moisture, in this case a river. At both the KOJE and BYST stations, the daily course in the middle of the day and in the afternoon hours shows large variations in the vapor pressure caused by turbulence, which indicates the pulling of humid air masses from nearby locations with high evaporation.

The lowest totals of interval with some discomfort (H30) were found at the CMSE station (LCZ 2). In 2011, great discomfort (H40) did not occur at all at the CMSE station. This was due to the microclimate of the enclosed courtyard, with small daily amplitudes of air temperature and water vapor pressure (Figure $4 b$ ).

As expected, low totals of interval with great discomfort (H40) and some discomfort (H30) were also found on the DDHL station. On the contrary, the low totals of intervals of discomfort at the HOLI station seem unusual, particularly because of the fact that the majority of stations with a similar location (BOT_PdF, BOT_PrF, and KOJE) and even 
the shady HODO station which has a very low impact of high temperatures on the formation of heat stress, showed relatively higher totals of intervals not only of great discomfort (H40), but also of some discomfort (H30). The reason is in the low water vapor pressure at this station. In comparison with other stations, the HOLI station has only a few potential sources of moisture.

Figure 4: The development of air temperature, water vapor pressure, and Humidex values at selected Metropolitan Station System Olomouc stations during the heatwave between August $22^{\text {nd }}$ to August 26 th 2011: a) BYST; b) CMSE; c) DDHL; d) DOMI; e) HOLI; f) KOJE and g) KRAK. Slika 4: Spreminjanje temperature zraka, parcialnega tlaka vodne pare in indeksa Humidex na izbranih merskih postajah metropolitanskega sistema postaj Olomouc v času vročinskega vala med 22. in 26. avgustom 2011: a) BYST; b) CMSE; c) DDHL; d) DOMI; e) HOLI; f) KOJE in g) KRAK.

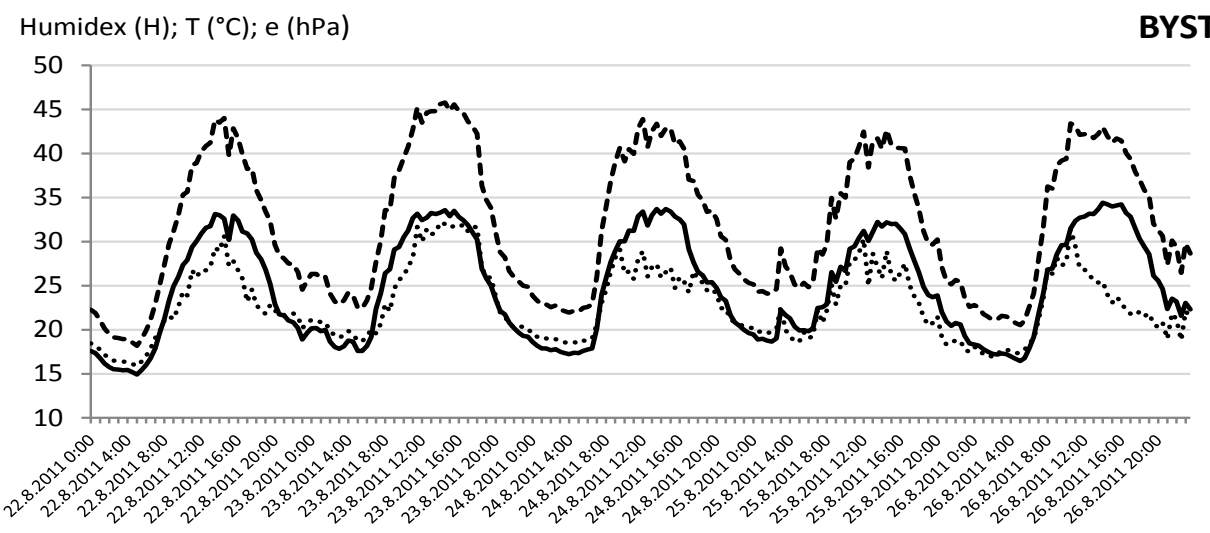

---- Humidex Temperature Water vapour pressure

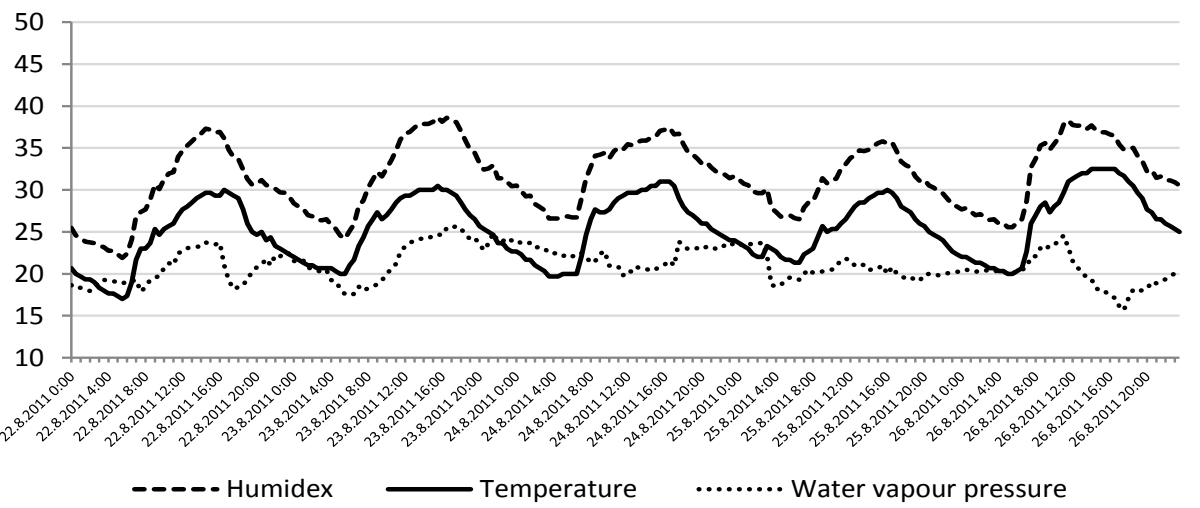


Humidex $(\mathrm{H}) ; \mathrm{T}\left({ }^{\circ} \mathrm{C}\right)$; e (hPa)

DDHL

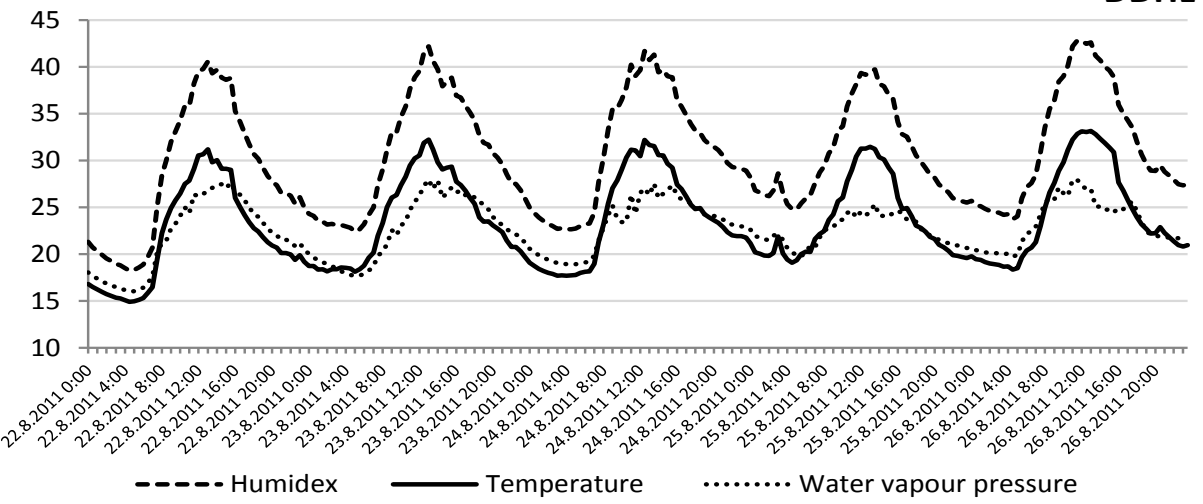

Humidex $(\mathrm{H}) ; \mathrm{T}\left({ }^{\circ} \mathrm{C}\right)$; e (hPa)
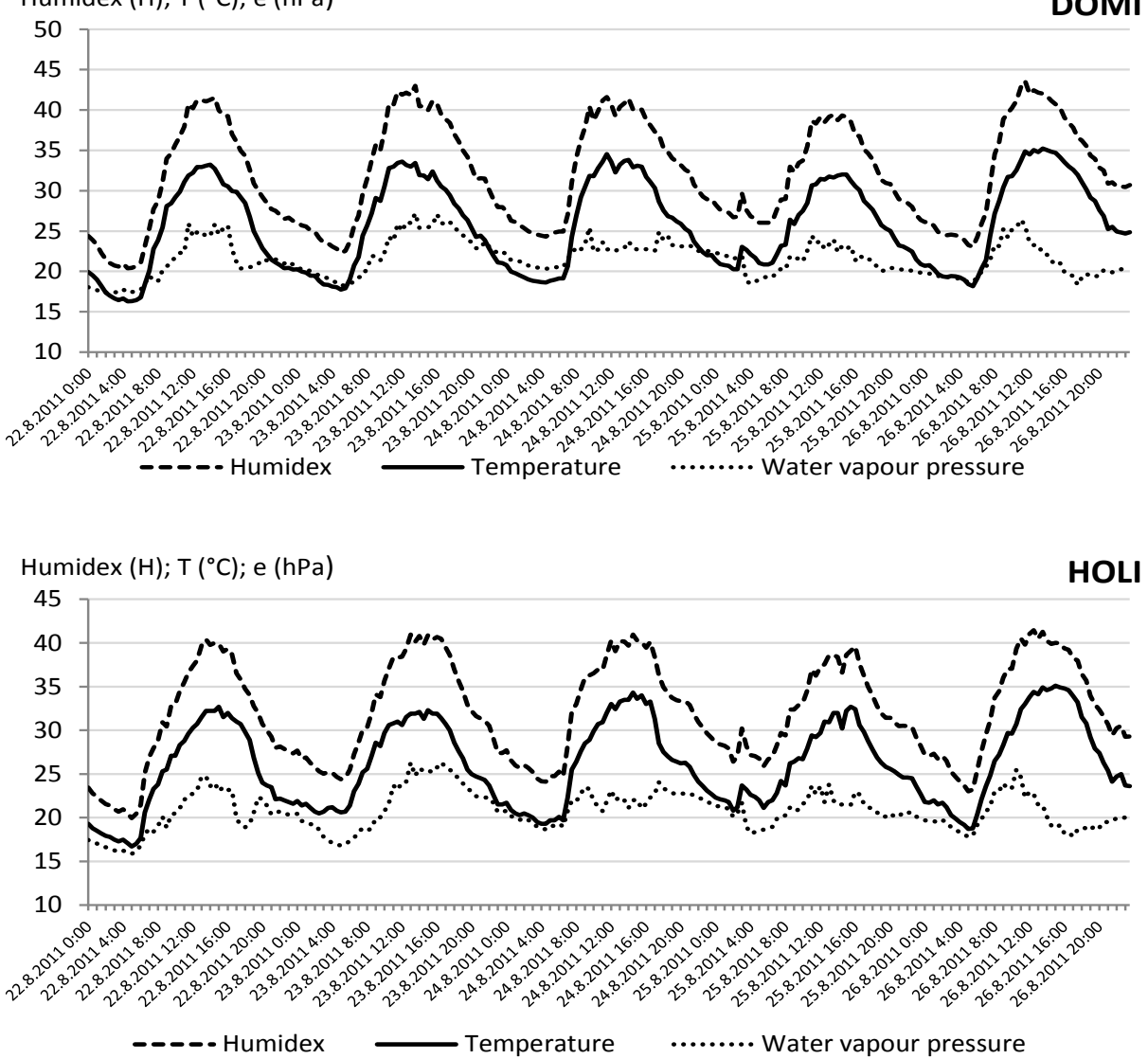

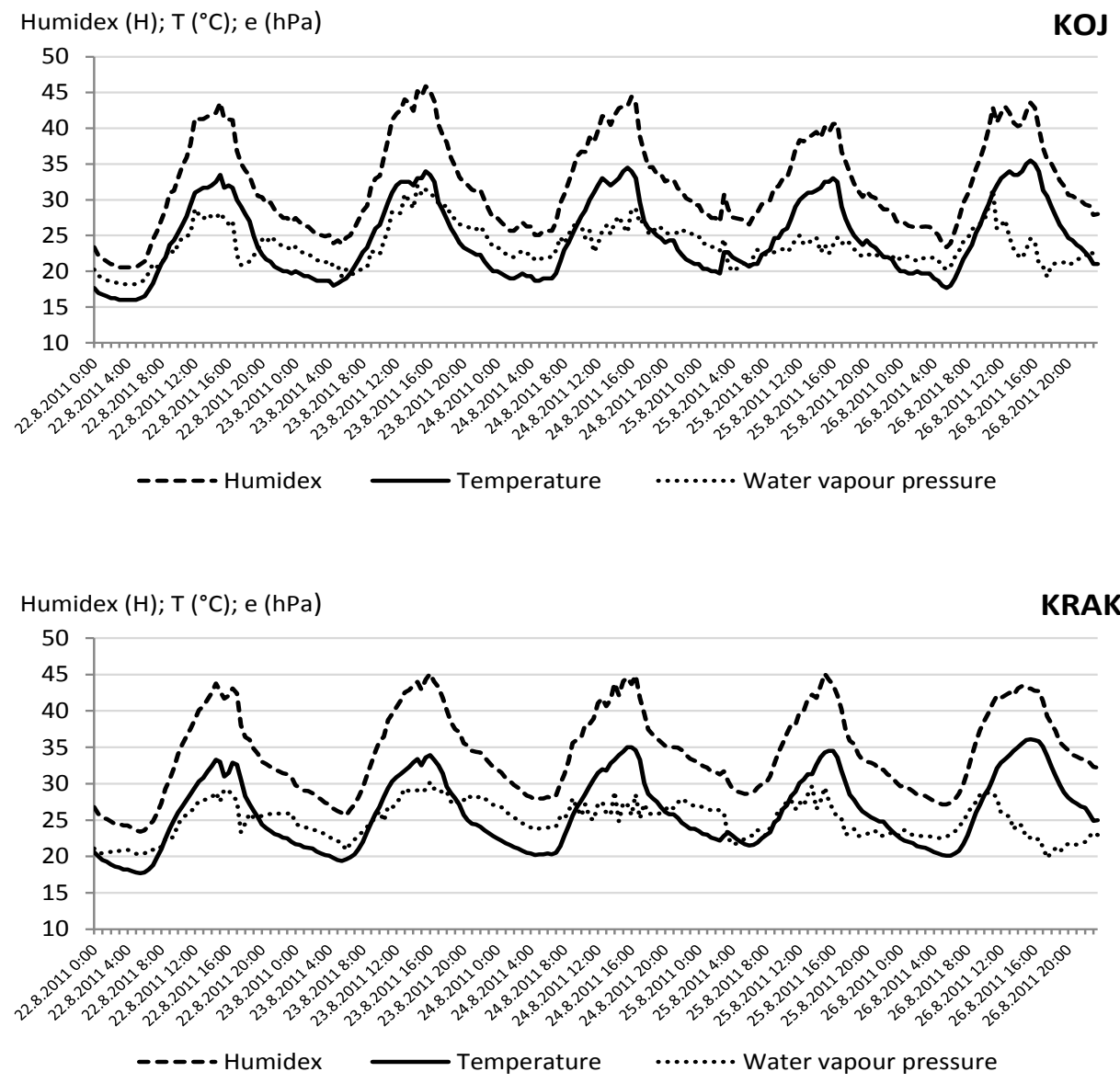

\subsection{Impact of heat stress on the population of the region through the example of mortality}

From the analyses of the spatial variability of the lengths of the intervals during which the threshold values of the air temperature above $25.0^{\circ} \mathrm{C}, 30.0^{\circ} \mathrm{C}$, and $35.0^{\circ} \mathrm{C}$ and $\mathrm{Hu}-$ midex values of H30, H35, H40, and H46 were exceeded, it is clear that the stress of the temperature-humidity conditions on the population during the summer has considerable intra-regional spatial heterogeneity because of the significant influence of the local climate and microclimate. Because of the dense network of stations, we were able to select a station that shows typical (average) temperature and Humidex values for the area of interest and, therefore, it can be considered representative on the regional level. Our analyses (Table 4) show that such a station is DOMI. The DOMI station is located in a 
courtyard of a park type with urban greenery and partially impermeable surfaces (Figure 2a). With regard to the spatial distribution of the population, such an environment can be considered as typical of Olomouc and its surroundings.

The DOMI station shows a typical daily course of temperature and Humidex values for Olomouc and its surroundings and, therefore, it was possible to further analyze the relationship between the maximum daily temperatures and mortality and between the maximum daily Humidex values and mortality. Notwithstanding other related factors or accompanying circumstances of the influence of heatwaves on mortality, it is clear that it is possible to find a clear relationship between the maximum daily temperature and mortality and the maximum daily Humidex values and mortality (Figures 5 and 6). Shifting days or the respective maximum daily temperature values/Humidex values back by one or more days because of the date of death unexpectedly did not improve the correlation coefficient.

Differences in trends of mortality with temperature and Humidex are negligible. In both cases the increase is statistically significant and non-linear (Figures 5 and 6). With maximum daily temperatures above $30^{\circ} \mathrm{C}$, the increase in mortality is still modest. When Humidex values extend above H40 (great discomfort) the increase in mortality is more significant, but in comparison with the sharp increase corresponding to Humidex values of 46 and higher, it is still relatively low. A significant increase in mortality therefore occurred only on days when the daily maximum Humidex value reached the level of 46 (dangerous) or the daily maximum temperature reached $35.0^{\circ} \mathrm{C}$. This is demonstrated in Figure 7 , where the sharp increase in mortality during heatwave from $17^{\text {th }}$ June to $23^{\text {rd }}$ June 2013 can be seen.

Figure 5: Relationship between the daily maximum Humidex value (categorized) and the change in the mortality rate (in \% of the mean mortality as 3-days moving average) in Olomouc and surroundings in the years 2010 to 2014.

Slika 5: Razmerje med dnevnimi maksimalnimi vrednostmi indeksa Humidex (kategoriziranimi) in spreminjanjem mortalitete ( $v \%$ od 3-dnevne drseče aritmetične sredine) v Olomoucu in okolici med letoma 2010 in 2014.

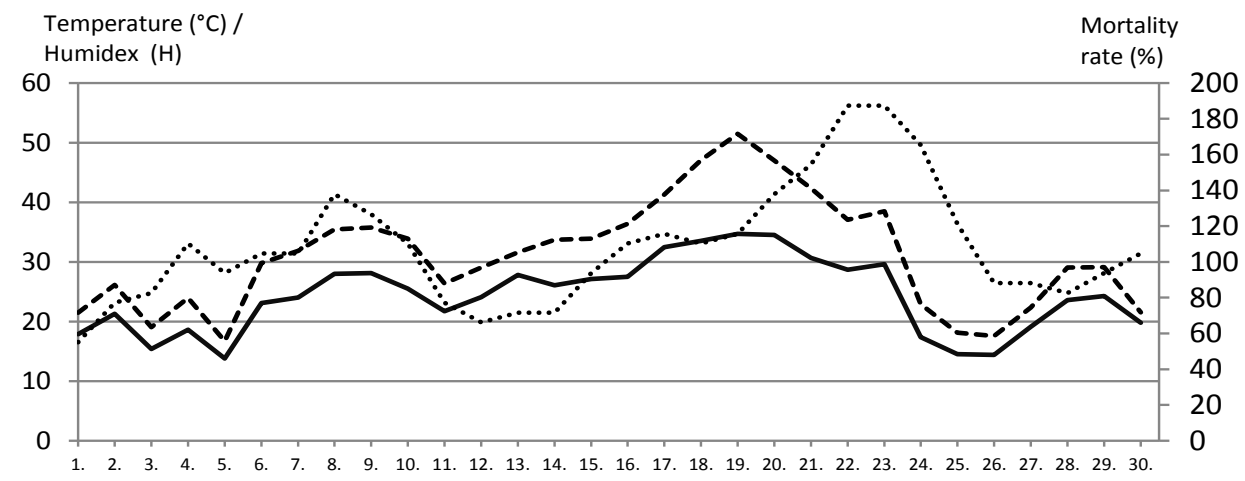


Figure 6: Relationship between the maximum daily temperature (categorized) and changes in mortality rates (in \% of the mean mortality) in Olomouc and surroundings in the years 2010 to 2014.

Slika 6: Razmerje med maksimalnimi dnevnimi temperaturami (kategoriziranimi) in spreminjanjem mortalitete ( $v \%$ od povprečne mortalitete) v Olomoucu in okolici med letoma 2010 in 2014.

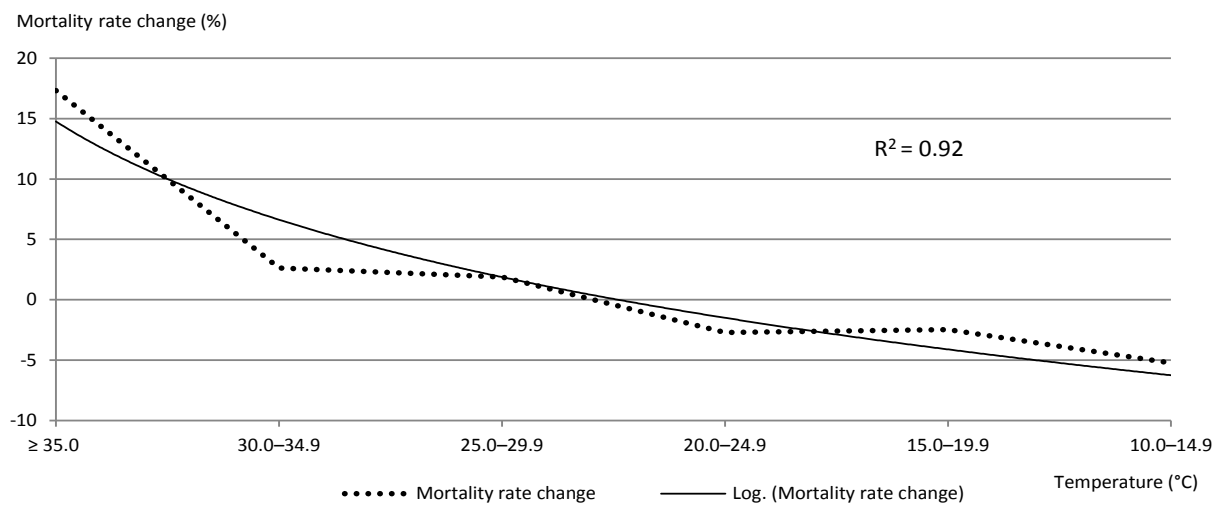

Figure 7: The maximum daily Humidex value, maximum daily temperature change and the change of the mortality rate (in \% of the mean mortality) in Olomouc and surroundings in June 2013.

Slika 7: Maksimalne dnevne vrednosti indeksa Humidex, maksimalne dnevne spremembe temperature in spreminjanje mortalitete ( $v \%$ od povprečne mortalitete) $v$ Olomoucu in okolici junija 2013.

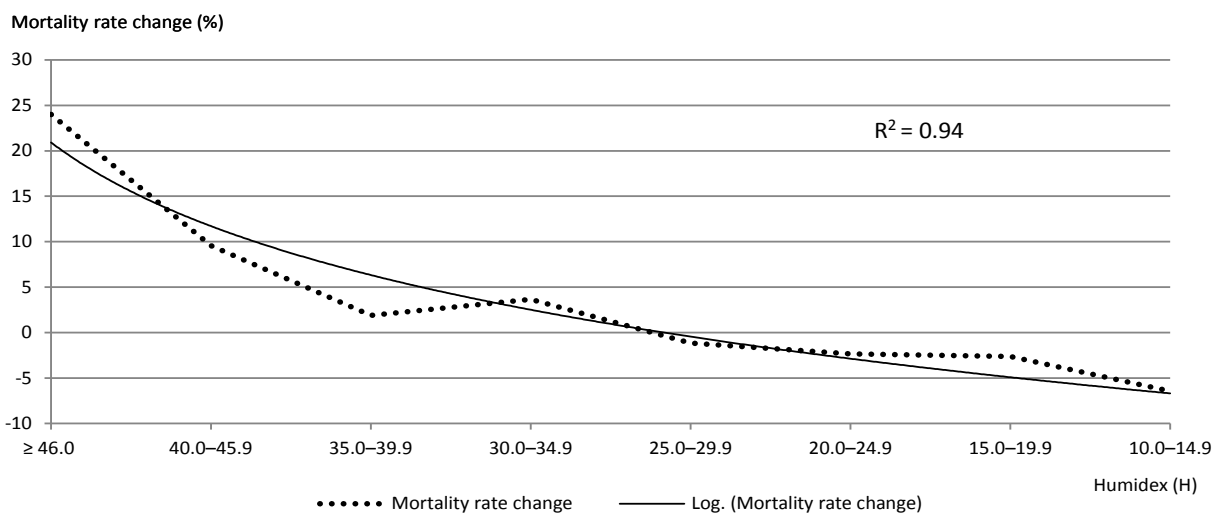




\section{DISCUSSION}

The biggest total amounts of time for which the threshold temperatures of $35.0^{\circ} \mathrm{C}$, $30.0^{\circ} \mathrm{C}$, and $25.0^{\circ} \mathrm{C}$ were exceeded occurred in the areas on the border of mid-rise, not very compact urban development and relatively open and well-insolated areas with the characteristics of zones LCZ 5 and LCZ 9 (LCZ D). This corresponds with the results of more recent studies on the heat island of a city, which imply that the highest daily temperatures are reached exactly in such types of environments (Houet, Pigeon, 2011; Stewart, Oke, Krayenhoff, 2014). High totals of time during which the temperature exceeded $35.0^{\circ} \mathrm{C}$ at the $\mathrm{CHVA}$ station $\left(\mathrm{LCZ} \mathrm{BD}_{\mathrm{w}}\right)$, which on average belongs to the colder stations, correspond with Stewart, Oke and Krayenhoff's (2014) founding that temperature in LCZ D may in some cases be even higher than the maximum temperature in LCZ 5 and LCZ 6. The smallest total amounts of time for which the threshold temperatures of 30.0 and $25.0^{\circ} \mathrm{C}$ were exceeded were found at the valley station DDHL (LCZ BA) near a forest and also at the station CMSE (LCT 2cc) in the city center. Such occurrence of cold fragments in the central parts of European cities when there is a positive energy balance has already been pointed out by Kłysik and Fortuniak (1999) through the example of Łódź (Poland).

Spatial differences between locations with high totals of intervals of temperatures above threshold values and locations with high totals of intervals of Humidex above threshold values were clearly demonstrable. Therefore, it turns out that not all the stations with the characteristics of LCZ 5 and 9 (D), typified by long intervals during which the threshold temperatures were exceeded, show long periods of time during which there was some discomfort (H30) or great discomfort (H40). It seems that a decrease in the relative humidity, together with increasing temperature, significantly reduces the resulting Humidex value unless there is a source of moisture in the neighborhood of the station (HOLI, CMSE, KOPE, and LETO). Analogously, and this is more serious, high maximum temperatures and high levels of water vapor pressure occur simultaneously at some locations (KRAK, KOJE).

It is clear that areas with low plants on moist soil may indicate a high maximum temperature, together with high water vapor pressure. This corresponds to the findings of Mayer and Höppe (1987), who justified the relatively lower values of water vapor pressure in an area of high vegetation by the fact that the vegetation in the period of maximum temperatures shows relatively low values of transpiration (closure of pores) and so does not contribute significantly to the value of water vapor pressure. As shown by the results presented here, the source of excessive water vapor pressure in the middle of the day and in the afternoon hours needs to be searched for in a wetland surface or in open water areas. At least in the middle of the day and during the afternoon hours of warm summer days, it is not possible to talk generally about the gradient of water vapor pressure between the urban and suburban landscape, as described, e.g., by Kuttler et al. (2007). Therefore, we can identify with the conclusions drawn by Fortuniak, Kłysik and Wibig (2006) that the gradients of water vapor pressure in the urban and suburban landscape are very difficult to define and the causes of their resulting spatial variability cannot be equated with the variability of the temperature field. Therefore, although there is criticism of Humidex (e.g., 
d'Ambrosio Alfano, Palella, Riccio, 2011), provided that air humidity affects thermal comfort, the Humidex assessment brings very valuable information about an important aspect of the spatial variability of heat stress in the urban and suburban landscape (i.e., at the local level).

Humidex values above $\mathrm{H} 46$ (dangerous) and temperatures above $35.0^{\circ} \mathrm{C}$ in Olomouc and its surroundings occurred relatively rarely, which corresponds to the results found for other Central European cities: Brno (Litschmann, Rožnovský, 2012; Dobrovolný et al., 2012) and Krakow (Bokwa, Limanówka, 2014). However, if they did occur, they were associated with a significant increase in mortality. The observed pattern of increased mortality together with maximum temperatures corresponds well with the detailed studies of the mortality rate caused by the heat carried out in the Czech Republic by Kyselý and Huth (2004a; 2004b) and Kyselý (2004). This finding is alarming if the predictions of greater frequency and extremity of high temperatures in Central Europe (IPPC, 2014b) are fulfilled.

Comparing the relative mortality and Humidex values with the relationship of the mortality rate and maximum temperature we found that, at the regional level, Humidex, in comparison with the maximum temperature, does not produce significantly more accurate information on the heat stress which warm weather causes to the population. This corresponds with the findings of Kyselý and Kř́žz (2003).

\section{CONCLUSIONS}

The longest intervals during which the threshold temperatures of $35.0^{\circ} \mathrm{C}, 30.0^{\circ} \mathrm{C}$, and $25.0^{\circ} \mathrm{C}$ were exceeded occurred in locations on the border of mid-rise and not very compact urban development and relatively open well-insolated open spaces. On the contrary, the shortest intervals were found in compact mid-rise in the center of the city with dense development and outside developments near a forest.

There are significant spatial differences between the locations with long intervals of high temperatures and locations with long intervals of high Humidex values. Water vapor pressure significantly modifies the field of heat stress in the city and its surroundings. The spatial-temporal variability of water vapor pressure should therefore be subject to more detailed research.

High Humidex values are observed at stations that have high maximum temperatures and are also exposed to an excessive supply of moisture as a result of evaporation resulting from artificial irrigation, naturally waterlogged soil, or water surfaces.

Assuming that the air humidity has an influence on the thermal comfort of a person, the temperature-humidity indices represent important aspect of the further refinement of the study of heat stress in urban and suburban landscapes on the local level.

When studying the effect of heat stress on the population at the regional level in a temperate climate, Humidex does not bring significantly better results than simple temperature indicators.

Humidex values above $\mathrm{H} 46$ (dangerous) and temperatures above $35.0^{\circ} \mathrm{C}$ occurred only infrequently in the conditions of Central European cities; they are associated with a significant increase in the mortality rate. 


\section{Acknowledgement}

This research project was funded by the Czech Grant Agency, Project No. 205/09/1297: "Multilevel analysis of the urban and suburban climate taking medium-sized towns as an example".

\section{References}

Błażejczyk, K., Twardosz, R., 2010. Long-term changes of bioclimatic conditions in Cracow (Poland). In: Błażejczyk, K., Twardosz, R. (eds.). The Polish climate in the European context: An historical overview. Houten, Springer Netherlands, pp. 235-246. DOI: $10.1007 / 978-90-481-3167-9$.

Bokwa, A., 2011. The urban heat island in Krakow, Poland: Interaction between land use and relief. Moravian geographical report, 19, 3, 2-7.

Bokwa, A., Hajto, M. J., Walawender, J. P., Szymanowski, M., 2015. Influence of diversified relief on the urban heat island in the city of Kraków, Poland. Theoretical and applied climatology, 122, 1-2, 365-382. DOI: 10.1007/s00704-015-1577-9.

Bokwa, A., Limanówka, D., 2014. Effect of relief and land use on heat stress in Kraków, Poland. Die Erde - Journal of the Geographical Society of Berlin, 145, 1/2, 34-48. DOI: 10.12854/erde-145-4.

Clarke, J. F., 1972. Some effects of the urban structure on heat mortality. Environmental research, 5, 1, 93-104. DOI: 10.1016/0013-9351(72)90023-0.

Curriero, F. C., Heiner, K. S., Samet, J. M., Zeger, S. L., Strug, L., Patz, J. A., 2002. Temperature and mortality in 11 cities of the eastern United States. American journal of epidemiology, 155, 1, 80-87. DOI: 10.1093/aje/155.1.80.

d'Ambrosio Alfano, F. R., Palella, B. I., Riccio, G., 2011. Thermal environment assessment reliability using temperature-humidity indices. Industrial health, 49, 1, 95106. DOI: 10.2486/indhealth.MS1097.

Dankers, R., Hiederer, R., 2008. Extreme temperatures and precipitation in Europe: Analysis of a high-resolution climate change scenario. Luxembourg, Office for Official Publications of the European Communities, 66 pp.

Dobrovolný, P., Řezníčková, L., Brázdil, R., Krahula, L., Zahradníček, P, Hradil, M., Doleželová, M, Šálek, M., Štěpánek, P., Rožnovský, J., Valášek, H., Kirchner, K., Kolejka, J., 2012. Klima Brna: Víceúrovňová analýza městského klimatu. Brno, Masarykova Univerzita, $200 \mathrm{pp}$.

Epstein, Y., Moran, D. S., 2006. Thermal comfort and the heat stress indices. Industrial health, 44, 3, 388-398. DOI: 10.2486/indhealth.44.388.

Fortuniak, K., Kłysik, K., Wibig, J., 2006. Urban-rural contrasts of meteorological parameters in Łódź. Theoretical and applied climatology, 84, 1/3, 91-101. DOI 10.1007/ s00704-005-0147-y.

Houet, T., Pigeon, G., 2011. Mapping urban climate zones and quantifying climate behaviors - an application on Toulouse urban area (France). Environmental pollution, 159, 8, 2180-2192. DOI: 10.1016/j.envpol.2010.12.027. 
IPPC, 2014a. Climate change 2014: Impacts, adaptation, and vulnerability. Part A: Global and sectoral aspects. Contribution of Working Group II to the Fifth assessment report of the Intergovernmental Panel on Climate Change. Field, C. B., Barros, V. R., Dokken, D. J., Mach, K. J., Mastrandrea, M. D., Bilir, T. E., Chatterjee, M., Ebi, K. L., Estrada, Y. O., Genova, R. C., Girma, B., Kissel, E. S., Levy, A. N., MacCracken, S., Mastrandrea, P. R., White, L. L. (eds.). Cambridge University Press, Cambridge, United Kingdom and New York, NY, USA, 1132 pp.

IPCC, 2014b. Climate change 2014: Synthesis report. Contribution of Working Groups I, II and III to the Fifth assessment report of the Intergovernmental Panel on Climate Change. Pachuari, R. K., Mayer, L. A. (eds.). Geneva, Intergovernmental Panel on Climate Change, $151 \mathrm{pp}$.

Kłysik, K., Fortuniak, K., 1999. Temporal and spatial characteristics of the urban heat island of Lodz, Poland. Atmospheric environment, 33, 3885-3895. DOI: 10.1016/ S1352-2310(99)00131-4.

Kovats, R. S., Hajat, S., 2008. Heat stress and public health: a critical review. Annual review of public health, 29, 41-55. DOI: 10.1146/annurev.publhealth.29.020907.090843.

Kuttler, W., Weber, S., Schonnefeld, J., Hesselschwerdt, A., 2007. Urban/rural atmospheric water vapour pressure differences and urban moisture excess in Krefeld, Germany. International journal of climatology, 27, 14, 2005-2015. DOI: 10.1002/joc.1558.

Kyselý, J., 2004. Mortality and displaced mortality during heat waves in the Czech Republic. International journal of biometeorology, 49, 2, 91-97. DOI: 10.1007/ s00484-004-0218-2.

Kysely, J., Huth, R., 2004a. Heat-related mortality in the Czech Republic examined through synoptic and 'traditional' approaches. Climate research, 25, 3, 265-274. DOI: $10.3354 / \mathrm{cr} 025265$.

Kyselý, J, Huth, R., 2004b. Úmrtnost související se stresem z horka v České republice v současném a budoucím klimatu. Meteorologické zprávy, 57, 113-121.

Kyselý, J, Kř́žz, B., 2003. High summer temperatures and mortality in the Czech Republic in 1982-2000. Epidemiologie, Mikrobiologie, Imunologie, 52, 3, 105-116.

Lavalle, C., Barredo, J. I., De Roo, A., Feyen, L., Niemeyer, S., Camia, A., Barbosa, P., 2006. Pan European assessment of weather driven natural risks. The EU regional policy online magazine 2006, pp. 1-11.

Lehnert, M., Geletič, J., Husák, J., Vysoudil, M., 2015. Urban field classification by “local climate zones" in a medium-sized Central European city: the case of Olomouc (Czech Republic). Theoretical and applied climatology, 122, 3, 531-541. DOI: 10.1007/ s00704-014-1309-6.

Lelovics, E., Unger, J., Gál, T., Gál, C. V., 2014. Design of an urban monitoring network based on local climate zone mapping and temperature pattern modelling. Climate research, 60, 51-62. DOI: 10.3354/cr01220.

Litschmann, T., Rožnovský, J., 2009. The incidence of heat index levels in urban areas of Brno. Sustainable development and bioclimate, Stará Lesná 5.-8. 10. 2009. URL: http://www.amet.cz/LitschmanRoznovsky2009.pdf (15.4.2015). 
Litschmann, T., Rožnovský, J., 2012. Zhodnocení indexu Humidex na území města Brna. 20th International Poster Day. Transport of Water, Chemicals and Energy in the Soil-Plant-Atmosphere System. Bratislava, 15. 11. 2012. URL: http://www.amet.cz/Humidex2012.pdf (15.4.2015).

Masterton, J. M., Richardson, F. A., 1979. Humidex: a method of quantifying human discomfort due to excessive heat and humidity. Downsview, Ontario, Environment Canada, Atmospheric environment, $45 \mathrm{pp}$.

Mayer, H., Höppe, P., 1987. Thermal comfort of man in different urban environments. Theoretical and applied climatology, 38, 1, 43-49. DOI: 10.1007/BF00866252.

Patz, J. A., Campbell-Lendrum, D., Holloway, T., Foley, J. A., 2005. Impact of regional climate change on human health. Nature, 438, 310-317. DOI: 10.1038/nature04188.

Stewart, I. D., Oke, T. R., Krayenhoff, E. S., 2014. Evaluation of the 'local climate zone' scheme using temperature observations and model simulations. International journal of climatology, 34, 4, 1062-1080. DOI: 10.1002/joc.3746.

Středová, H., Středa, T., Litschmann, T., 2015. Smart tools of urban climate evaluation for smart spatial planning. Moravian geographical reports, 23, 3, 47-56. DOI: 10.1515/ mgr-2015-0017.

Tan, J., Zheng, Y., Tang, X., Guo, C., Li, L., Song, G., Zhen, X, Yuan, D., Kalkstain, A. D., Li, F., Chen, H., 2010. The urban heat island and its impact on heat waves and human health in Shanghai. International journal of biometeorology, 54, 1, 75-84. DOI: 10.1007/s00484-009-0256-X.

Tomáš, M., 2012. Letní teploty vzduchu v Olomouci v letech 2010-2011 z hlediska teplotního konfortu člověka. Meteorologické zprávy, 65, 3, 75-82.

Vysoudil, M., Frajer, J., Geletič, J., Lehnert, M., Lipina, P., Pavelková-Chmelová, R., Řepka, M., 2012. Podnebí Olomouce. Olomouc, Palacký University, 211 pp.

WMO, 2008. Guide to meteorological instruments and methods of observation. Geneva, World Meteorological Organization, 677 pp. URL: https://www.wmo.int/pages/ prog/gcos/documents/gruanmanuals/CIMO/CIMO_Guide-7th_Edition-2008.pdf (4.11.2015).

\section{TOPLOTNI STRESV URBANEM IN SUBURBANEM OKOLJU TER NJEGOVA PROSTORSKA SPREMENLJIVOST NA PRIMERU SRE- DNJE VELIKEGA MESTA}

\section{Povzetek}

Zmerne geografske širine so območja, kjer lahko predpostavljamo povečano smrtnost zaradi toplotnega stresa. Dejavniki, ki ga povzročajo, so dobro poznani, v desetinah znanstvenih člankov so predstavljeni tudi številni pokazatelji, s katerimi ga lahko kvantificiramo. Mnogo manj pozornosti je posvečeno preučevanju prostorske spremenljivosti toplotnega stresa, obenem pa nove ugotovitve o mestni klimi kažejo, da so razlike $v$ temperaturnem polju v mestu večje, kot smo mislili doslej. Takšne 
razmere kažejo na potrebo po podrobnejših preučitvah prostorske variabilnosti toplotnega stresa $\mathrm{v}$ mestih.

$\mathrm{V}$ študiji smo poskušali ovrednotiti prostorsko spremenljivost toplotnega stresa $\mathrm{v}$ srednje velikem mestu na primeru Olomouca in njegove okolice (Češka republika) ter ugotoviti, v kolikšni meri nam standardni podatki o temperaturah in indeks Humidex pojasnjujejo vrednosti toplotnega stresa na lokalnem nivoju. Uporabili smo podatke 14 merskih postaj iz metropolitanskega sistema postaj Olomouc (Metropolitan Station System Olomouc, MESSO), ki so razmeščene v različnih urbanih in suburbanih okoljih. Z analizo podatkov smo ugotavljali dolžino obdobij s preseženimi mejnimi temperaturami $\left(25,0^{\circ} \mathrm{C}, 30,0^{\circ} \mathrm{C}\right.$ in $35,0^{\circ} \mathrm{C}$ ) ter mejnimi vrednostmi indeksa Humidex (rahlo neugodno H30, zelo neugodno H40, nevarno H46) na posameznih lokacijah. Da bi pojasnili, v kolikšni meri oba pokazatelja uspešno pojasnjujeta toplotni stres na regionalnem nivoju, pa smo analizirali še razmerje med vsakim od obeh pokazateljev ter povečano mortaliteto.

Rezultati kažejo, da so se obdobja s preseženimi mejnimi vrednostmi temperatur pojavljala na merskih postajah med območji s srednje visokimi zgradbami (LCZ 5) in dobro osončenimi odprtimi javnimi površinami ali redko pozidanimi območji (LCZ 9/D). Območja z najkrajšimi obdobji preseženih mejnih vrednosti temperatur smo našli v bližini gozda (LCZ BA) in tudi v mestnem središču (LCZ 2cc). Prav tako se je izkazalo, da niso bila na vseh postajah $\mathrm{z}$ daljšimi obdobji preseženih mejnih vrednosti temperatur zabeležena tudi daljša obdobja s preseženima mejnima vrednostima indeksa Humidex H30 in H40.

Ugotovili smo, da so bile razlike v trendih mortalitete glede na temperature in indeks Humidex zanemarljive. Statistično značilno povečanje mortalitete se je pojavljalo v dnevih, ko je maksimalna dnevna vrednost indeksa Humidex dosegla 46 (nevarno) oziroma ko so najvišje dnevne temperature dosegle $35,0{ }^{\circ} \mathrm{C}$.

Parcialni tlak vodne pare je pomembno vplival na razporeditev toplotnega stresa $\mathrm{V}$ mestu in okolici. Podatki o vlažnosti zraka nam torej dajejo pomembne informacije o prostorski spremenljivosti toplotnega stresa na lokalnem nivoju, pri preučevanju učinkov toplotnega stresa na prebivalstvo na regionalnem nivoju pa nam indeks Humidex ne daje nič boljših rezultatov kot podatki o temperaturah.

\section{(V slovenski jezik prevedel Karel Natek)}

